\title{
PRISONERS' STRUGGLES
}

\author{
CSC's COVID-19 Response: \\ Inside Canada's First Federal Penitentiary Outbreak \\ at Mission Medium \\ Dean Roberts
}

\section{PREFACE}

The following is an account of the first major COVID-19 outbreak in a Canadian prison that took place at Mission Medium Institution located in the community of Mission, British Columbia, Canada in April 2020 and its impacts on institutional life that still reverberate today. During the outbreak at this federal penitentiary operated by Correctional Service Canada (CSC), a total of 120 federally sentenced men were infected with the coronavirus (CSC, 2021), one of which died (CSC, 2020). In chronicling the measures taken in a stated effort to prevent and manage the spread of COVID-19, including lockdowns and other restrictive measures, I argue that CSC's public health response to the pandemic has subjected its prisoners to torturous conditions of confinement that are psychologically harmful, which will ultimately undermine public safety down the road.

\section{APRIL TO JULY 2020}

I am one of those guys who endured a quarter-year lockdown at Mission Medium Institution in British Columbia, Canada. Over the previous two years, we had survived an assortment of Inmate Wellness Committee (IWC) firings, removals, transfers, and finally a six-month stint with no committee at all. Management refused to process unit purchase orders, hold family socials, or facilitate IWC photocopying of legal paperwork for the prisoner population. After a few complaints and grievances were filed, the warden approved an interim committee made up from the 14-person body of elected unit reps. Each of our living units consist of two sides of 23 or 24 prisoners who had already independently elected one guy to represent their collective concerns to the IWC.

As one of those reps, I went to our first meeting and was selected with another fellow to be our two-man interim-IWC as a four-month band-aid fix. This was done at the end of February 2020 and only to help encourage the population to submit enough names to hold a prison-wide population 
election. I was preparing to go in front of the Parole Board of Canada in May for passes or Day Parole.

Unfortunately, the coronavirus had other plans. On 2 April 2020, two men who contracted COVID-19 were removed from their living units and placed in the old segregation building, now named the Medical Intervention Unit (MIU), while the rest of the prison was placed on isolation lockdown. We had no idea of how things were to proceed. After 48 hours of silence and confusion, the prison's TV information channel announced that there was a positive case of COVID-19 and the lockdown was for "transmission risk management".

Through the last two weeks of March, we had been expecting something, but not this wholesale black hole of fear, confusion and abandonment. The institution had already been placed on a "modified routine" with prisoners being confined to the inside common areas of our respective living units during the day and wide-open everything in the evenings. No elders, chaplains, visits, or group volunteers were allowed on site.

On 4 April 2020, my cell door cracked open and I walked out to the front desk. Staff there told me that we needed to stay locked up until some more tests came back, and that all prisoners should report any symptoms they experience for the next day or two. Health services would come around to do temperature tests on everyone and any "infected" men would be moved to the MIU. They summed it up by saying it should all be sorted out within a week. As the IWC Chair and still a unit representative, I went around my 96cell building ( 4 wings of 24 cells) and talked to each man through his door window. I did so without a face mask or gloves. The only recommendation I was given was to wash my hands when I got back to my cell.

That night, I sat in my seven-by-ten-foot cage and worried about what was happening. I tried to get information, but the staff were just as unsure of everything as I was and seemed afraid to even talk to me. They also were not wearing PPE or following any observable transmission risk protocols. Then I started to feel unwell. My stomach hurt. I could not eat food and had a headache unlike anything I had ever known - it was a beast of an illness of unrivaled proportions.

On 5 April 2020, I did not even get out of bed and did not eat all day. Strangely, I also could not go to the bathroom. My stomach was a hard knot and my head felt like it was being ripped open from the inside out, top down. I briefly wondered if this could be the new virus on TV, but a man 
across the hall from me had just gone through a really bad stomach flu so I chalked it up to the same thing.

On 6 April 2020, my condition had not improved. I told the unit staff that I felt sick and asked to see health services. A nurse came and performed a COVID-19 nasal swab test, as well as ones for blood pressure and bloodoxygen. I was given Tylenol and told they would check in every day.

On 7 April 2020, the nurses had trouble taking my blood pressure. I was shaky and cold, even though my temperature was hot. My oxygen levels had dropped to alarming levels, in the low 70 percent. I was hazy and got really confused trying to explain things to them. They brought in an oxygen tank and spoke to the doctor on the phone. It was decided that I should be sent to the hospital. Immediately, like right the F now! The only thing that seemed real to me at the time was an alarming change in attitude of the otherwise typically indifferent nurses.

At this point, nobody was wearing masks or gloves, so I clearly saw the looks of concern - even fear - at my condition. An ambulance came and I had the inglorious status of being the very first prisoner sent to the Abbotsford Hospital from Mission Medium Federal Institution.

The next five days were mostly a blur. The double, even triple walls of plastic and PPE were like something right out of a movie set, like that Dustin Hoffman one, Virus. I vaguely recall another man from my living unit arriving in the bed beside me some hours later. That night he crashed, and I heard him being induced into a coma, along with the oddly consistent screams of somebody a few stalls away, while I drifted in and out of consciousness. The Emergency Ward was all noise and screaming and fear. All the time.

Two days later, I was moved to the third floor of the hospital and learned that five other prisoners were there too, along with ten guards camped outside our rooms. I remember hearing about some kind of portable medical unit from the army was being sent to the hospital parking lot on the day and that multiple ambulances had lined up at Mission Medium Institution to bring a slew of infected prisoners out. By 11 April 2020, I was mostly stable and to make space at the hospital they sent me back to Mission.

When I arrived the place changed considerably. At first, our prisoner population of 298 had been left on 24-hour lockdown for six straight days - no showers, phone calls, fresh air or meaningful human contact. Prisoners were just left alone the cells and given two meals a day. At mealtimes, staff 
ordered you to place a chair inside the cell door and stand at the back of your cell. A Styrofoam take-out tray from the institutional kitchen was dropped on the chair and the door slammed as fast as they could. By day seven, a shower program was designed where one guy was permitted out for 20 minutes a day, total, with face masks and gloves enforced for staff and prisoners alike. Separate COVID-19 zones were implemented for the testpositive guys. My unit ended up with almost 60 percent of us getting the virus. Eventually, they just opened all of the areas and had us use universal precautions at all times.

When I got back from the hospital a staff member told me to call my sister. Apparently, she had been "banging at the gate" demanding to know was happening to her brother. I could not imagine the mental anguish my family was going through. That night, I skipped the shower and used my 20-minutes out-of-cell time to call her and my dad. The fear was palpable over the phone. A shared sense of trepidation only heightened by all the media stories that never seemed to bring much clarity. It was wonderful to finally hear their voices, though, limited as our time was. Just to be able to encourage and love one another felt great. I was weak and broken inside and the road to recovery would end up being very long. My COVID-19 consequences affected my lungs and the ability of my body to get oxygen into my blood. I tired very fast and felt a burning pain pressing in on my chest every day. Just walking one hundred feet exhausted me.

That first month was harried and rough. I remember them announcing that an Indigenous man had died at the hospital. I knew him well. A lot of the other men were still there and remembering the TV coverage of Italy at the time, I prepared for the worst. To see rows and rows of body bags lined up.

I can accept that CSC, as a whole, was in no way ready for the scope of this pandemic. The reality is that no part of the government was ready on day one. In those first four weeks, literally hundreds of heads had to get together to come up with a plan. However, those of us locked up in our cages did not know anything. The trickle of information was stopgap and limited at best. The unit staff were afraid to interact with us. In fact, one officer told me that, in the beginning, they were actually ordered by management not to wear facemasks because they might appear intimidating or frightening to the prisoners. What? Within that first week, the guard union called an unsafe work environment and threatened to walk off over the issue. Then it was all masks and gloves, all the time. 
By the end of April 2020, some Westworld-like cleaners in space suits showed up and followed us around for our 20-minutes out of cell time. There were many times when our daily 20 -minute shower times were skipped, missed or forgotten altogether. Often, we went 48-hours without any meaningful human contact - no opportunity for a shower or a phone call to a loved one. Even lawyer calls were sporadic and limited.

While there were many failures during the pre-outbreak timeline, after Dr. Bonnie Henry and the Fraser Health Authority joined with the system, they did manage to clamp down and face the situation head-on. The infection count peaked at 120 prisoners. And by the end of April 2020 we were suddenly "managing our strategy". On 13 May 2020, the Warden announced that we were at COVID-zero. If we could keep it that way for 14 more days, we should be ready for our "new normal". On 28 May 2020, Dr. Bonnie Henry announced on TV that the outbreak at Mission Medium was officially over.

Well... yes and no. I read the summer issue of William Head Institution's Out of Bounds Magazine and got upset as I read about their level of Management-to-IWC interaction: regular meetings, communiqués, memos, and rapid-fire understanding and results. This occurred all while we were in a fog of war, often unsure where things stood from one day's shift to the next.

Prison is an experiment in behavioural conditioning. The one constant is routine. Every day, the predictable and understood is sacrosanct. However, in the chaos of COVID-19, every day was unknown. Each shift and staff complement had a different idea of how to run the shower program, how to feed us and manage clean laundry. Locked in a 7x10 brick cage, uncertainty can wreak havoc on a person's mind, with the smallest change triggering wild emotional swings, unexplainable rage, despair, and soul-crashing confusion.

As an IWC rep, I put in requests to have meetings with upper management, with social distancing and facemasks of course. Denied. I asked for management to make a phone call to the living unit and talk to me there. This never happened for five months. I was contacted by an official from the Office of the Correctional Investigator and she started to call in every week to stay on top of the situation, and my number one issue: the need for open, effective communication with management. Still nothing. The unknowing made the situation worse. Seven weeks in a row she contacted the Warden's Office to request he facilitate a phone meeting with the IWC and they never responded. I reached out to my community 
contacts and asked them to e-mail a request to CSC Commissioner Anne Kelly and copying it to the Warden. Desperately, I pleaded for some kind of intervention to help the men know what was going on and to be a part of the discussions. Nothing came from that either.

In the first week of May 2020, a full month into this 23-hour-and-40minute-a-day isolated confinement, the early heat of summer started to really cook us. The stress and anxiety began to shift into high gear. Sitting alone in my cell, I would hear odd, random screaming and yelling, as well as strange, scary crashes and thumps. I was in William Head Institution in 2002 when Ottawa changed it from medium security to minimum security overnight. They shipped 93 men out over the first few weeks. The resulting overcrowding at Mountain Institution was extreme. In those first six months, we had seven suicides. I still remember the sound of a man so lost in the throes of despair that he was willing to take his own life, sounds that were starting to become familiar again.

Locked up in Mission during the early months of COVID-19, I started to feel unexplainable irritability and anxiety one minute, then sudden withdrawal or even cognitive dysfunction the next. I was also still in my own state of physical recovery from the virus. I developed a deep pain over the top half of my chest, and a persistent, staccato-like dry cough that never brought anything up. I seemed to exhaust not only easily, but instantly.

Almost worse than the solitary confinement was the absence of routine. Any given day, staff seemed to invent a new routine for showers and phone calls. This amounted to men being left in their cages with little to do, but roam the confusing landscape of loneliness and chaos. Within the first month of quarantine protocols, some men developed bed sores and body pain from being sedentary and lying in bed all day.

Some concerned unit staff, on their own initiative, actually reached out to me and a few other Peer Health prisoner representatives one day. They let me, masked and gloved, go around the unit and talk to men through their cell doors. More often than not, I had no answers for each guy, and I was just as frustrated as they were with the way things were being handled, but the face-to-face human contact and peer-support seemed to offer a brief respite - a shared notion that we could make it through this.

Sadly, I encountered some men who had taken to scarring their face with long slashes and bloody lines. Others who had slammed their heads into the wall, so consumed by the helplessness, isolation and fear of the unknown, 
did not even understand why. One guy even sewed his lip shut - literally and without staff noticing. Fortunately, some of the Peer Health prisoners were also volunteering for out-of-cell laundry work. They convinced him to cut the stitches and eat again.

Another guy admitted to considering an assault on the next guard who opened his door. His thinking being that he would get 4-hours-a-day out of his cell at the maximum-security segregation unit at Kent Institution. At least there he would be treated like a human being. We talked about the shared frustration of near-constant lockdown in a tiny cell, about the lack of communication, and the almost invisible line of fear between us and staff. We also discussed how strange it is to see other human beings literally afraid to go near you. Eventually the guy was able to see the root of his anger and recognize the flawed thought patterns of that kind of drastic solution. He agreed that the obvious long-term negative outcomes outweighed any possible gains and committed to sticking it out.

Time and again, I would listen to a 20-minute to half-hour shared venting session. Inevitably revolving around frustrations - sometimes near-paralyzing - over the inhumane treatment. Through early May 2020, the men in my unit started to go through extended periods of smashing something against the steel doors and the bars on our cell windows. There was no rational purpose. Just raw emotion. The sudden flush of shared connection in those moments could sometimes be overwhelming. Realizing that somebody else felt what you felt, was angry as you were angry, and together we kicked and banged out our anxiety, frustration, and rage.

Unfortunately, as the IWC chair, I was never able to see the other five living units in our institution. Even more perplexing, after a couple of weeks of being able to see the men in my own unit (every other day), upper management sent an email to unit staff "ordering" them to prevent the IWC from speaking with the men in a representative capacity without prior authorization from said upper management.

On 1 June 2020, they announced that we would be getting 45-minutes outside in the big yard - once every seven days mind you, and in small groups of 12 men only - with real, actual fresh air and sunshine. Two weeks later, we were also allowed out of our cells for 45-minutes a day still in our small cohorts of $12 \mathrm{men}$. That is $23^{1 / 4}$-hours-a-day in a 7 x 10 foot box with your head 18 inches from the toilet. The scariest part was when one officer, one of the hardest around, came to me and said, "We're worried... 
every time we open a cell door, it's like seeing some of these guys'souls die in their eyes".

In the community, a lawyer named Donna Turko had been hearing of the struggles from many of her clients and reached out. Prisoners Legal Services had offered some funding and she called in to speak with the IWC. I shared with her what I knew, what I had seen, and she filed a habeas corpus on 17 June 2020 in my name as the IWC for the population against Mission Medium for the extended, solitary confinement-like treatment created by this "medical isolation". 1

I was deeply affected by the mental anguish and suffering going on around me, and I had no way knowing what was going on in the other five living units. I sent letter to Melissa Ridgen, an investigative reporter at APTN, to Commissioner Kelly and the warden. I asked, begged and prayed for communication: a meeting, a phone call, anything from upper management to say that we were in this together and there was a plan. However, three months in, I had been told nothing. So we went ahead with the habeas and I asked for a clause: if the Warden would meet with the IWC and make a strategy for the future we'd withdraw. Radio silence followed.

Somehow, in a legal system where an emergency habeas has six days under the law to go in front of a Judge, the Crown pushed us off for five weeks. Donna, my lawyer, was told that the warden was on vacation. By the time we did see the judge on 23 July 2020, Mission Medium was on a fast-track three-phase path to reopening: prisoners were in the unit common areas for the whole day, non-contact visits resumed, canteen was open, and we could even go to the gym once a week or so. We withdrew the application.

In the aftermath, I found myself labeled as less-than. I was even named in the Warden's Affidavit. I mean, I expected I would be as Chair of the IWC. But I was named individually - as a convict, with every inherent association to my crimes and victims. What did this have to do with a habeas on behalf of 300 men? My application was seven pages long. The warden's response was 136 pages. My institutional case management team (CMT) wrote me up as challenging the system and I had no support for anything.

Shortly after that, I heard a conversation with a person in the community who sits on the Occupational Safety and Health board (OSH) with the Fraser Health Authority. He said that this institution had no plan whatsoever to open us up. Back in the thick of things, Fraser Health was arguing with 
the joint to take control and let us out, that the outbreak was actually over, but the institution's plan was to stay on 231/4-hour lock up until a vaccine was found. Literally, until a vaccine was found! That said, this person felt that without the habeas application, we might still be locked up at that point in the pandemic.

\section{AUGUST 2020 TO AUGUST 2021}

Into the fall of 2020, things started to look better. I had my first meeting with management near the end of September. The warden, deputy warden and assistant warden of operations, came around to each unit individually and met with the respective unit reps. They visited my unit last. It was the first real meet-and-greet where each side got to speak openly and share ideas since March 2020.

While greatly appreciated, the meeting felt more like a random political campaign than anything actually addressing our issues. We brought up a lot of concerns and ideas. There were lots of nods and shrugs, but little commitment to any proposed resolutions. One month later, the only item to be resolved was that I got access to the IWC office at least one afternoon per week when no other prisoner are in the building's corridor.

Also in early October 2020, the IWC (down to just me by then) finally had a meeting with the other five living-unit reps, outside, in the tennis court, with each of us a good 10-feet apart. Finally, we got to see one another and a lot was accomplished from our side. Seven months after this chaos began and we were one jail again. At least for one morning.

After the initial panic, fear, dread, and shock of actually being shipped to the hospital with a blood oxygen level so low that even the mean guards were white-faced and nice to me, my path to recovery remained brutal - six months of barely being able to drag myself across the outside field. I felt it in my lungs and had to sit exhausted after just one lap, but the sunshine was a glory of unparalleled joy. It was shocking to experience how wonderful the sun was after so long of nothing. I still got winded near instantly and realized that I was suffering from the reverse COVID-19 curse: I'd packed on a lockdown 30 and nothing I did wanted to move it.

My parole hearing was on 26 October 2020. I did not have much support from CSC, but I intended to ask for more than I expected to get. Going in with the usual lifer mindset: ask for everything, expect nothing. However, 
time and the world had changed since my original application and the board wanted us to update some things, get more information on other matters. We decided to postpone the hearing.

Maybe 2021 will be my year I thought when it started. Again, I seem loath to lose my deepest addiction - an almost childlike dependency on common sense. Nearly three decades in this crazy machine called CSC, and they still have not beaten the optimist out of me. So if not outright common sense, maybe something similar. I do not want to break the wheel. I do not even want to remake it. I just want to see the darned thing actually work. Unfortunately, 2021 became more of the same. My Parole hearing was an exercise in COVID-19 protocols and procedure with no real connection or understanding. Maybe next year.

\section{MY LEGAL PERSPECTIVE}

Near the end of 2020, the West Coast Prison Justice Society released a report titled Solitary By Another Name. I had shared more than a few phone calls and letters with Jennifer Metcalfe of Prisoners' Legal Services as she was preparing this report and found it remarkable. The Government of Canada, for years, already understood - or should have understood - everything that I was seeing prisoners around me experience during this pandemic.

In August 2011, the Special Rapporteur on Torture and Other Cruel, Inhuman or Degrading Treatment or Punishment submitted an interim report to the United Nations General Assembly with respect to solitary confinement, which he defined as: "the physical and social isolation of individuals who are confined to their cells for 22 to 24 hours a day" (Méndez, 2011). Of particular concern to him was prolonged solitary confinement, meaning any period of solitary confinement in excess of 15 days. At that point, according to the medical literature that he surveyed, some of the harmful psychological effects of isolation can become irreversible.

The special rapporteur concluded that given the negative psychological and physiological effects of solitary confinement, which can manifest after only a few days, the practice should only be used in exceptional circumstances, as a last resort, for as short a time as possible, and subject to minimal procedural safeguards. He called on the international community to impose an absolute prohibition on indefinite solitary confinement and on placements exceeding 15 consecutive days. 
The Special Rapporteur's work informed the most recent version of the United Nations' Standard Minimum Rules for the Treatment of Prisoners ("SMRs"). In December 2015, the UN General Assembly unanimously adopted a revised version of the SMRs, known as the "Nelson Mandela Rules". The Mandela Rules state as follows (my emphasis added in underline and italics):

\section{Rule 43}

In no circumstance may restrictions or disciplinary sanctions amount to torture or other cruel, inhuman or degrading treatment or punishment. The following practices, in particular, shall be prohibited:

a. indefinite solitary confinement;

b. prolonged solitary confinement;

c. placement of a prisoner in a dark or constantly lit cell [...]

\section{Rule 44}

For the purpose of these rules, solitary confinement shall refer to the confinement of prisoners for 22 hours or more a day without meaningful human contact. Prolonged solitary confinement shall refer to solitary confinement for a time period in excess of 15 consecutive days.

The Mandela Rules define solitary confinement as the confinement of a prisoner for 22 hours a day or more without meaningful human contact. CSC resisted this label, maintaining that administrative segregation as practiced in Canada does not constitute solitary confinement.

In his 17 January 2018 ruling of a case between the BC Civil Liberties Association and the Attorney General of Canada regarding segregation, ${ }^{2}$ Judge Justice Leask stated under section 137:

On the basis of the evidence detailed in this section of my Reasons, I am satisfied that administrative segregation as currently practiced in Canada conforms to the definition of solitary confinement found in the Mandela Rules. In particular, I find as a fact that inmates in administrative segregation are confined without meaningful human contact. I base this finding in part on the evidence of Mr. Somers, Mr. Clark, Dr. Haney, and the inmate witnesses. 
Section 31 to 37 of the Corrections and Conditional Release Act (CCRA) and section 13 to 23 of the Corrections and Conditoonal Release Regulations (CCRR) provide the basic framework for administrative segregation. Section 31 of the CCRA sets out the purpose and grounds for ordering administrative segregation:

(1) the purpose of administrative segregation is to maintain the security of the penitentiary or the safety of any person by not allowing an inmate to associate with other inmates.

(2) the inmate is to be released from administrative segregation at the earliest appropriate time.

In August on 2017, a review of Commissioners Directive 709 - which governess administrative segregation - included:

CD 709 improvements to the conditions of confinement, including in; (Part iii) a minimum of two hours out of cell daily, including the opportunity to exercise for at least one hour everyday outdoors, weather permitting;

(Part iv) and daily showers, with the time spent not to be included in the inmate's two hours out of cell.

In the earlier referenced case concerning the effects of segregation, Judge Justice Leask ruled under section 247:

I find as a fact that administrative segregation as enacted by s. 31 of the CCRA is a form of solitary confinement that places all Canadian federal inmates subject to it at significant risk of serious psychological harm, including mental pain and suffering, and increased incidence of self-harm and suicide. Some of the specific harms include anxiety, withdrawal, hypersensitivity, cognitive dysfunction, hallucinations, loss of control, irritability, aggression, rage, paranoia, hopelessness, a sense of impending emotional breakdown, self-mutilation, and suicidal ideation and behavior. The risks of these are intensified in the case of mentally ill inmates. However all inmates subject to segregation are subject to the risk of harm to some degree. 
He went on to include in section 249 that "many inmates are likely to support permanent harm as a result of their confinement" and in section 250 that "[n]egative health effects can occur after only a few days in segregation, and those harms increase as the duration of the time spent in segregation increases". He also noted in section 252 that "[ $\mathrm{t}]$ he 15-day maximum prescribed by the Mandela Rules is a generous standard given the overwhelming evidence that even within that space of time an individual can suffer severe psychological harm".

Neither the CCRA or the CD's explicitly provide authority to impose a lockdown. Section 53 of the $C C R A$ does grant authority to the warden to authorize an "exceptional search" of all prisoners in a penitentiary or a part of it, but the warden is still responsible under the law to uphold the rest of the Act as well.

On 23 April 2020, Correctional Investigator Dr. Ivan Zinger (2020) issued a COVID-19 Status Update in which he affirmed that the violations of universal human rights of the kind I described earlier in this piece were not justifiable even in the context of the pandemic. Two days later, the Prime Minister responded that his government was looking into the report. Nothing further was heard from the Prime Minister's Office.

Federal penitentiary lockdowns of the kind routinely used during the pandemic are contrary to the liberty and security of a person's rights under Section 7 of the Canadian Charter Rights and Freedoms, as well as contrary to the core principles "of least restrictive measures and retained rights" in the $C C R A$, specifically under sections 4(c) and 4(d). These institutional lockdowns also violate the $C C R A$ by failing to take into consideration the state of health of prisoners or that the living conditions imposed undermine personal dignity.

In 1999, a CSC Security Bulletin on Lockdowns notes that all prisoners are required to be provided with at least one hour of daily outdoor exercise, plus a daily shower, and reasons for the lockdown and duration. ${ }^{3}$ Under the Charter, wardens must fulfill their responsibilities for the care, custody and control of prisoners, and the management of the penitentiary, in a way that does not subject prisoners to cruel or unusual treatment or punishment, or deprive them of their life, liberty or security of the person not in accordance with principles of fairness and justice. Moreover, even in the newly created Structured Intervention Units that replaced segregation in CSC institutions require prisoners to be provided with an opportunity to spend "at least" four 
hours outside their cells, and to interact with others for at least two hours per day. Such legal requirements have been frequently thrown to the waste side at Mission Medium Institution during the pandemic.

This is occurring despite the British Columbia Court of Appeals 2018 ruling on "Solitary Confinement", which noted that it is unconstitutional to lock-up any prisoner in their cell for longer than 22 hours per day. The same court, along with decisions in jurisdictions such as the Yukon and Ontario, all agreed that solitary confinement is cruel and unusual treatment due to its long-term, irreversible and negative effects. This being the case, one wonders why this practice has been used in the name of public health for almost two years now.

\section{CONCLUSION}

Solitary by Another Name states that, "The federal government dropped its solitary confinement appeal to the Supreme Court of Canada on April 21,2020 , ostensibly agreeing that isolating an individual for 22 hours per day for more than 15 days or without independent external review is unconstitutional. Yet nothing was done to address the situation at Mission. By that point, nearly 300 prisoners at Mission had already been in solitary confinement for 23.5 to 24 hours per day for 19 days... Prisoners remained in solitary confinement, with less than two hours out of cell per day, well into June 2020" (West Coast Prison Justice Society, 2020, p. 35). ${ }^{4}$

Through the first half of 2021, the prisoners at Mission Medium continued to be subject to many prolonged periods of "Imposed Lockdowns" due to contact tracing, staff shortages, and CSC's own COVID-19 protocols that left us locked up for up to 72 hours continuous without even a shower. The constant, fear, and anxiety of COVID-19 has been overwhelming and oppressive, further amplifying the already high stress and anxiety of being isolated in a cell for days on end. We have been under incredible duress, stress, anxiety, and PTSD from the year-and-a half state of "Modified Routine" and uncertainty of COVID-19. Even while complying with every rule and change, and lining up to be first to get the Moderna vaccine shots in April and June 2020.

Back in July of 2020, Anne Kelly, the Commissioner of Corrections, released a shiny new Commissioner's Directive (CD) known as CD 822: Modified Routines in the Time of COVID-19. CSC also created Shaping 
the New Normal, a massive multi-hundred page tome of all things COVID, providing details for every institutional function or activity.

However, a year and a half into this crisis, I do not see CSC actually following it clearly. Each institution implements their own version of the rules or strategy. CD 822 , section 27 defines prisoner interaction and mask usage, stipulating that "Social Distancing is to be the required norm. Only when that is not possible are face masks to be added". However, the warden at Mission insists that face masks be worn at all times. Even in the middle of the outside yard one hundred feet from the next person, prisoners must be in full mask or suffer institutional repercussions. Even prisoners outside getting photographs must keep their face mask on. This kind of procedural oddity just amplifies the distrust and anxiety over CSC's process and response to this situation. Thankfully, in August 2021, the new COVID-19 manager determined that prisoners outside could now take off their facemask, our first big step into the new world.

The hardest part for me has been the nearly empty acknowledgement of Indigenous culture or ceremony. Shaping the New Normal gives clear and direct protocols for the Elders to hold Indigenous Ceremony, and yet Mission Medium denied the Elders access to our spiritual grounds for over 459 days. That is a real number.

A year after my "recovery" I still have cognitive shorts in my brain strange lapses in the connection between the motor skills for speech and my brain ability to match words with understanding. My circle of friends make fun of the strange wordings that I create and it is funny, which is easier than being afraid. What if this never gets better? It is hard to find ground some days. At least I usually mean what I say even if I don't say what I mean. I have picked up the catchphrase, "That's what I said, you just heard me differently".

Most of my physical things are healed, the memory stuff carries the deepest fears. It is part of why I am willing to keep in the IWC path even though it is not helping me get out any time soon. Busy, busy, busy, always forcing my mind to process and work. I am in college and writing two of my own novels for the same reasons. I am terrified of losing memory functions.

I have seen every other faith represented in this population managed through the chapel, and yet the almost one third of Mission that is First Nations have had nothing. A person who passed very early in this pandemic and we have not had a ceremony to let him go. Another man died in my unit 
a few weeks before that and at least we smudged his cell, but still nothing for the population. And now, another person was laid out literally right in front of my cell on the floor as the familiar sounds from the hospital came back: staff and paramedics working frantically for 53 minutes straight -53 minutes until he had a pulse again. Scary sounds. Unfortunately, he too succumbed to his condition and died in the hospital shortly afterwards.

The Kamloops Residential School revelations have brought back a whole world of hidden pain, loss and fear. My family is two generations removed from Residential School and that is not protection. It is nothing. I have heard too many stories of dark nights hidden in the corner of a room as somebody's little brother or sister was thrown into a wheelbarrow and carted out, limp. Stories the world pretended not to hear. Well, Kamloops was just the beginning - there were more, far too many more. I do not think we are even half done there.

After weeks of TV coverage of the Kamloops Residential School tragedy, on 18 June 2021, CSC finally offered the first ceremony to the prisoners of Mission Medium. 459 days after the last spiritual ceremony was offered, we were permitted to attend the Sacred Grounds for 15 minutes to make seven prayer ties and offer them to the fire. 459 days later. It is hard to find ground at all.

My spiritual and cultural identity is my balance and strength to face the struggles of the day. 459 days alone, abandoned, isolated, and under anxiety, stress, fear, and the ever present unknown has been difficult to say the least. And ironically, they only offered the ceremony after nearly 80 percent of the prisoners had received their second vaccine shots.

We still do not have a vision for the future, no "three-staged plan", no communiqués or that outline the "next step". We are six independent and isolated living units that are forbidden to interact with one another. The uncertainty is the greatest evil in an environment that thrives on consistency and communication.

\section{ENDNOTES}

July 23, 2020, Supreme Court of BC file \# 30627.

Docket S150415 British Columbia Civil Liberties Association v. Canada (Attorney General) 2018 BCSC 62.

3 See Security Bulletin: Institutional Lockdowns, No 99-07 (12-04-1999); CCRR supra note 45, section 83(2)(d). 
4 Roberts v BC 2020 BCCA 176.

\title{
REFERENCES
}

Correctional Service Canada [CSC] (2021) Inmate Testing and Case Summary, Ottawa. Retrieved from: https:/www.canada.ca/en/correctional-service/campaigns/ covid-19/inmate-testing.html

Correctional Service Canada [CSC] (2020) "COVID-19 related death of an inmate", Ottawa - April 16. Retrieved from: https://www.canada.ca/en/correctional-service/ news/2020/04/covid-19-related-death-of-an-inmate.html

Méndez, Juan E. (2011) Interim Report, New York: United Nations Special Rapporteur on Torture and Other Cruel, Inhuman or Degrading Treatment or Punishment August 5. Retrieved from: https://digitallibrary.un.org/record/710177\#record-filescollapse-header

West Coast Prison Justice Society (2020) Solitary by Another Name: The Ongoing Use of Isolation in Canada's Federal Prisons, Vancouver.

Zinger, Ivan (2020) COVID-19 Status Update, Ottawa: Office of the Correctional Investigator of Canada - April 23. Retrieved from: https://www.oci-bec.gc.ca/cnt/ rpt/pdf/oth-aut/oth-aut20200423-eng.pdf

\section{ABOUT THE AUTHOR}

Dean Roberts is currently imprisoned at Mission Institution (Medium). He can be reached by mail at:

\author{
Dean Roberts \\ Mission Institution (Medium) \\ 8751 Slave Lake Street \\ PO Box 60 \\ Mission, British Columbia \\ V2V 4L8
}

